Purdue University Purdue e-Pubs

\title{
Geotechnical Engineering Education in Nigeria: Reflecting on University versus Industry Reality
}

Ifeanyi Okpala

Purdue University Northwest

Jiliang Li

Purdue University Northwest

Follow this and additional works at: https://docs.lib.purdue.edu/aseeil-insectionconference

Okpala, Ifeanyi and Li, Jiliang, "Geotechnical Engineering Education in Nigeria: Reflecting on University versus Industry Reality" (2018). ASEE IL-IN Section Conference. 3.

https://docs.lib.purdue.edu/aseeil-insectionconference/2018/transf/3

This document has been made available through Purdue e-Pubs, a service of the Purdue University Libraries. Please contact epubs@purdue.edu for additional information. 


\title{
Geotechnical Engineering Education in Nigeria: Reflecting on University versus Industry Reality
}

Mr. Ifeanyi Okpala, Purdue University - Northwest

Prof. Jiliang Li P.E., Purdue University - Northwest

\begin{abstract}
In Nigeria, a developing nation striving for a sustainably built environment, the academics and practicing engineers jointly play a major role in shaping Geotechnical Engineers. From undergraduate studies to Industrial Work Experience, there is a need to appraise the ecosystem to ensure that learning is experiential and devoid of bottlenecks while individuals graduate from the university to face industry realities.
\end{abstract}

To cultivate sound professional development, this paper aims to provide an overview of the inherent challenges faced by students in Nigeria while indulging in Geotechnical Engineering education and practice. Sectors assessed include the Geotechnical coursework, Local Industrial Work Experience and Technical Application Software mainly used in the Civil/Geotechnical Engineering industry. In addition, the availability and extent of influence of relevant professional bodies is considered.

Major results include the presence of few geotechnical courses in the civil engineering curriculum (as opposed to structural engineering courses) and few positions available for the Students' Industrial Work Experience Scheme placement due to only a handful of companies predominantly providing Geotechnical Engineering services. Also students' lack of exposure to state-ofthe-art technology in the classroom makes it hard for nominalization of illustrations taught. Even in the community of 
the Nigerian Society of Engineers, there is no affiliate comprising of solely Geotechnical Engineers hence, there appears to be few platforms where Geotechnical engineers and students alike can come together, under one umbrella.

This paper will bring, to the fore, a fair share of diverse global experiences which engineering students, in Nigeria, have in the course of their university education. This will then stake a case for engineering educators worldwide to develop a well-rounded mindset when developing solutions which will be useful all over the world.

\subsection{Introduction}

Idris and Rajuddin (2012) rightly noted that the origin of engineering education can be traced from two different distinct roots. First is the trade apprenticeship education where the trainees of the local trade program studied to advance their practical and theoretical knowledge of their various trades. The second, as reported by Booth (2014), can be traced through the college or university that recognizes natural science which serves as a key point for specialization to an application in engineering.

According to the Accreditation Board for Engineering and Technology (ABET) in 2007, "Engineering is the profession in which a knowledge of the mathematical and natural sciences gained by study, experience, and practice is applied with judgment to develop ways to utilize economically the materials and forces of nature for the benefit of mankind". "Geotechnical Engineering, in the same vein, is the branch of Civil Engineering concerned with the analysis, design and construction of foundations, slopes, retaining structures, embankments, tunnels, levees, wharves, 
landfills and other systems that are made of or are supported by soil or rock" (EJGE, 2017).

For individuals to become geotechnical engineers or any type of engineer at all, formal higher education is required and in different climes, there are minimum qualification standards which they are required to meet in order to be allowed to design or build or maintain any form of societal infrastructure.

It is a veritable fact that the technological and industrial development of any nation depends on its ability to develop its citizens especially in the area of science and engineering. In Nigeria, a developing country, there are problems of rapid urbanization and threats to wellbeing of communities most especially, the city of Lagos which has an estimated population of over 20 million people according to the World Population Review. This makes it the 7th largest city in the world. To bridge enormous socio-economic gaps of the city, one of the most critical challenges common to all its inhabitants must be overcome - social infrastructure. A very good way through which sufficiency of physical assets can be achieved is the development of quality engineers for sustainable design of facilities for social services. Of this required skill-set, geotechnical engineering is key and in Nigeria, the academics and practising engineers jointly play a major role in shaping future Geotechnical Engineers.

\subsection{Statement of the Problem}

The quality of engineering graduates from universities and polytechnics in Nigeria has been a major concern over the years. Many practitioners in the civil engineering industry complain that graduates possess inadequate skills, low practical know-how and 
low confidence, especially in the current era of cutting edge technology (Idris and Rajuddin, 2012). Going by the quality of training acquired by the engineering graduates of tertiary institutions in Nigeria, many of them are engaged in advanced training by companies in order to equip them with requisite skills to enable them perform adequately in the first intake level.

The aforementioned calls for an in-depth study of not just the end result but of the process undergone by engineering students in the Federal Republic of Nigeria. From undergraduate studies to Industrial Work Experience, there is a need to appraise teaching practice to ensure that learning is experiential and devoid of challenges while students graduate from the university to face industry realities.

Information to be succinctly shared in this paper are mostly those gotten from my first-hand experience while undergoing university education (between year 2010 and 2015) which culminated in a Bachelor of Engineering (Civil) degree at the Federal University of Agriculture, Abeokuta, Nigeria.

\subsection{Aim and Objectives}

This paper aims to provide an overview of the inherent challenges faced by students in Nigeria while acquiring Geotechnical Engineering education and practice.

To cultivate sound professional development of geotechnical engineering students, the objectives are:

1. To educate the public by drawing from both first-hand and documented students' experience in recent times.

2. To make a case for a well-rounded mind-set by educators when developing solutions which will be useful all over the world. 


\subsection{Justification and Scope of Study}

Due to the rising trends of globalization in quality education, there is a need to boost uniform quality assurance processes at different levels such as universities, professional bodies, regional and international levels. That is why there are associated accreditation processes which serve to recognize and acknowledge the valueaddition in transforming students admitted to these programs into capable technical professionals, having sound knowledge of fundamentals and an acceptable level of professional skills and personal competence for ready employability in responsible technical assignments (Memon et al, 2009). Considering that sectors assessed include the Geotechnical coursework, Local Industrial Work Experience and Technical Application Software mainly used in the Civil/Geotechnical Engineering industry, this will allow for educators around the world to be fully aware of the situation of students undergoing engineering education in Nigeria.

In addition, the availability and extent of influence of relevant professional bodies will be considered hence, this will allow members of these bodies have first-hand of the situation which is largely as a result of their actions/inactions. Also, this should make every concerned individual pay attention to the psychological journey a student embarks upon while graduating from the institution to join the labor market.

The scope of this paper borders around strictly higher education in Federal Universities with no particular emphasis on monotechnics and polytechnics in Nigeria. The ones owned by the federal government are more populated and thus, presents a sample space illustrating the real situation to a great deal. Also, statistical data is 
available on the Federal Universities as compared to the State Universities and the newly established private Universities.

In addition to circumstances I have been in, I will also share excerpts of honest experiences of former classmates and colleagues at present.

\subsection{The Nigerian University System}

As at first quarter of 2012, there are 123 universities in Nigeria (aside Monotechnics, Polytechnics, and Colleges of education). There are 36 Federal universities, 37 state universities and 50 private universities (according to Act 9 of 1993 constitution) offering over a thousand different programs. The Universities' activities are regulated and controlled by the National University commission (NUC), an agency under the umbrella of the Ministry of Education. NUC is responsible for the program accreditation and setting enrolment benchmarks for the Universities according to their capacity. NUC works in collaboration with the Joint Admissions and Matriculations Board (JAMB) a body established by law to conduct matriculation examinations into tertiary institutions in Nigeria.

Enrolment into Nigeria Universities has witnessed sporadic changes from 1948 when the total student enrolment at University of Ibadan (previously University College Ibadan) was 104 (Njoku, 2002). The number has grown sporadically till date. 
Table 1.Total Enrolment in federal University by major Discipline (2001-2006)

\begin{tabular}{lccccc}
\hline DISCIPLINES & $2001 / 2002$ & $2002 / 2003$ & $2003 / 2004$ & $2004 / 2005$ & $2005 / 2006$ \\
\hline ADMINISTRATION & 29,407 & 29,741 & 45,247 & 47,886 & 29,757 \\
AGRICULTURE & 18,557 & 27,201 & 30,457 & 26,455 & 22,022 \\
ARTS & 31,182 & 31,456 & 35,585 & 38,589 & 33,998 \\
EDUCATION & 33,782 & 33,798 & 48,230 & 48,889 & 49,247 \\
ENGR/TECHNOLOGY & 47,278 & 50,983 & 51,816 & 59,702 & 57,824 \\
ENVIR.SCIENCE & 10,864 & 14,676 & 18,036 & 18,853 & 17,968 \\
LAW & 14,395 & 13,896 & 15,430 & 18,506 & 16,299 \\
MEDICINE & 26,360 & 25,426 & 28,001 & 31,540 & 25,884 \\
PHARMACY & 5,727 & 5,873 & 5,967 & 5,538 & 4,740 \\
SCIENCE & 59,361 & 74,933 & 78,761 & 97,724 & 75,187 \\
SOCIAL SCIENCE & 45,320 & 38,154 & 54,450 & 52,924 & 56,725 \\
VETERINARY MEDICINE & 3,474 & 3,365 & 7,273 & 3,771 & 3,735 \\
TOTAL & $\mathbf{3 2 5 , 7 0 7}$ & $\mathbf{3 4 9 , 5 0 2}$ & $\mathbf{4 1 9 , 2 5 3}$ & $\mathbf{4 5 0 , 3 7 7}$ & $\mathbf{3 9 3 , 3 8 6}$ \\
\hline
\end{tabular}

Source: Agboola and Elinwa (2013)

Based on data mined by Agboola and Elinwa (2013), table 1 shows the Total enrolment in Federal Universities by major Disciplines. Science and Engineering faculties have the highest enrolment of student (except for 2003/2004 when social science had more than Engineering) in Federal Universities, meaning that many students preferred mathematical oriented courses to the other courses.

In also assessing the number of teachers in federal universities by major disciplines, they observed that Science and Engineering have the highest number of Instructors. The Teacher to Student ratio for Engineering (1:30), Sciences (1:32), Veterinary Medicine $(1: 12)$ and Medicine (1:16) means that the Science and Engineering faculties are actually taking more students than their capacity.

\subsection{Concerns of Engineering Education in Nigeria}

As carefully explained by Agboola and Elinwa (2013), the major concern of engineering education in Nigeria is poor funding, nonavailability of basic facilities and poor staffing. The recorded teacher to student ratio in a Federal University in Nigeria is 1:30, a 
ratio worse in most state Universities. The funds available to most Universities are inadequate and the number of yearly intake tends to increase without control as universities offering Engineering programs admit more students than their capacity, a situation that has led to overcrowding of the classes and available facilities.

In addition, the accreditation body is yet to perfect its evaluation criteria to reveal the short comings in engineering education, the latest round of accreditation (2007) only approved 56\% of the engineering programs (fully accredited) while the rest are either on interim or denied status. One will expect that these problems should be feedbacks needed to improve the engineering education but that has not been the case over the years. The need to seek help from proven accreditation bodies like ABET should be top priority on the agenda of NUC, also NUC should allow a professional institution like the Council for the Regulation of Engineering in Nigeria (COREN) to run the accreditation of their respective programs to upgrade its credibility. A global accreditation body will be of great help to developing countries like Nigeria to upgrade their engineering education to improved standards being daily set.

The standard of engineering education is falling in Nigeria; a situation leading to brain drain of good students to developed countries where it appears engineering education is of higher quality. The country has huge human resources in engineering education but inadequate investment in research and development is repelling them to the industry or outside the country where there is far better opportunities. This is a major cry by the Academic Staff Union of Universities (ASUU) during their nationwide strikes which happens on an average of once in 4 years. 


\subsection{Geotechnical Engineering Education in Nigerian}

\section{Universities}

In Nigerian Federal Universities, Geotechnical Engineering is taught under the Civil Engineering Bachelor or Master's degree program however, students are allowed to take up electives which signify that they intend to major in the sub-discipline at that educational level. Generally, apart from the occasional use of audio-visual equipment for presentations, students' lack of exposure to state of the art technology in the classroom makes it hard for visualization of illustrations shared during lectures.

Mahmud et al (2012) correctly reported that the current engineering curriculum used in universities cannot create wealth nor foster the much-needed development in Technology and engineering expertise. This is largely due to the gap the engineering graduates find between tutelage provided and the reality after school. The current curriculum for training engineering graduates emphasises the fundamentals e.g. Physics, Mathematics and chemistry and a bit of technology (Onwuka, 2009). These emphases can only lead to partial design. Partial design is that approach to design that emphasises basic engineering disciplines without a holistic look at the product development process (Pugh, 1993).

In the current curriculum arrangement, a student is admitted to study Engineering for five years after passing through the Senior Secondary School with five credits in subjects that include: Mathematics, Physics, Chemistry, Mathematics and English Language. The first year is spent on general/Natural Sciences while from the second year, the student takes up core engineering courses. At the end of the final year there is a technical project 
which the student, either as an individual or group with others is expected to carry out before graduation.

\section{Geotechnical Engineering Coursework}

The civil engineering curriculum showcases the presence of few Geotechnical courses in the Civil Engineering curriculum (as opposed to structural engineering courses). In the first authors' academic transcript upon graduation in 2015, there are five (5) geotechnical engineering courses as opposed to seven (7) centred on analysis and design of structures.

\section{Local Industrial Work Experience}

With the way the academic curriculum is structured, there is a Students' Industrial Work Experience Scheme (SIWES) which is a cumulative 12-month period where students are attached to relevant industrial affiliations in order to gain valuable work experience. The major challenge here is the availability of few

positions for the Industrial attachment due to only a handful of companies predominantly providing Geotechnical Engineering services. These days, most of the industrial experiences are gathered in places that are not cognate with the specific engineering discipline. The exercise is seen more as requirement to go to the next stage than as part of the learning process

\section{Technical Application Software}

During engineering education in Nigerian Universities, the major technical application software taught are Autodesk AutoCAD, CSI Orion, Prokon, Scale and Ansys. In the classroom, the focus is 
usually on AutoCAD but when the student is in the final year and hence, is working on an undergraduate thesis, the remaining are encouraged for design and analysis. In learning how to use this, some have a head-start during their industrial work experience while others resort to self-study under the guidance of the research advisor.

\section{Availability and Extent of Influence of NSE and COREN}

The Nigerian Society of Engineers (NSE) is the umbrella body of all professional engineers in Nigeria while the Council for the Regulation of Engineering in Nigeria (COREN) is the body mandated to regulate and control the training and practice of engineering in Nigeria and to ensure and enforce the registration of all engineering personnel (i.e. Engineers, Engineering Technologists, Engineering Technicians, and Engineering Craftsmen) and consulting firms wishing to practice or engage in the practice of engineering. Assessment of engineering programs is carried out by the National Universities Commission (NUC) in conjunction with COREN and this is a very important periodic exercise. In addition, the NSE tries to assist with the professional development of young members who are predominantly students but apart from technical sessions at the annual National Engineering Conference and some educational competitions, she does not directly offer much more positives.

\subsection{What is Needed?}

In consonance with recommendations by Mahmud et al (2012), note that for a robust and efficient Engineering education system that can be productive, the following must be worked on:

a. Physical infrastructure 
This includes buildings-administration, laboratories, libraries (with adequate contact and subscription to relevant dat base around the world) and workshops. These are very important because they create the required enabling environment for teaching and learning.

b. Human resources

A critical mass of very sound, qualified, up-to-date and professionally certified human resource base is required. A good engineer should possess Sound judgement, Technical ability and ability to visualise (Kofoworola, 2003). This is one of the issues that hamper the progress of engineering education in the existing format. University Education system can employ graduates who do not have working experience and recruit them for teaching because they had good grades. Even when the implementation of Industrial attachment trainings has been closely followed, it does not equate with actual working experience for the same period.

\subsection{Conclusion}

As Mahmud et al (2012) rightly stated, Nigeria desires to be among the 20 most developed economies by the year 2020. This vision will require an accelerated improvement of engineering education curriculum, product design and development culture. Engineering education is indeed one of the strongest pillars of economic growth and national development of any nation. The authors hereby suggest that engineering educators, researchers and industrial collaborators worldwide should strive to develop a wellrounded mind-set when developing solutions which will be useful all over the world. Taking the step from University Geotechnical Engineering education to work in the industrial is one which greatly defines the future of the individual hence, it should be properly done. 


\section{References}

Accreditation Board for Engineering and Technology (ABET). (2007) "Criteria for Accrediting Engineering Programmes Baltimore: Accreditation Board for Engineering and Technology (ABET)" Engineering Accreditation Commission, 2007. Retrieved from: http://www.abet.org/policies.html.

Agboola, O. P. and Elinwa, U. K. (2012). "Accreditation of Engineering and Architectural Education in Nigeria: the way forward." Proceedings of $2^{\text {nd }}$ World Conference on Educational Technology Researches - WCETR2012. pp 836 - 840

Booth, S. (2004). Engineering education and the pedagogy of awareness. In Brown, S.(Ed) Effective Learning and Teaching in Higher Education (PP 9-23). London: Taylor \& Francis e-Library.

Electronic Journal of Geotechnical Engineering (EJGE). (2012) "What is Geotechnical Engineering?" Electronic Journal of

Geotechnical Engineering. ISSN 1089-3032. Retrieved from: http://www.ejge.com/Definition.htm

Idris, A. and Rajuddin, M. (2012). "The Trend of Engineering Education in Nigerian Tertiary Institutions of Learning towards Achieving Technological Development." Proceedings of International Conference on Teaching and Learning in Higher Education (ICTLHE 2012) in conjunction with RCEE \& RHED 2012. pp $730-736$

Kofoworola, O.F. (2003). "Engineering Education in Nigeria Present Learning Systems and Challenges for the Future". The Australasian Association for Engineering Education Inc. Australasian Journal of Engineering Education. pp 2-7. 
Mahmud, J. O., Mohd Ismail, M. S. and Mohd Taib, J. (2012).

“Engineering Education and Product Design: Nigeria's

Challenge." Proceedings of International Conference on Teaching and Learning in Higher Education (ICTLHE 2012) in conjunction with RCEE \& RHED 2012. pp 679 - 684

Memon, J. A., Demirdogen, R. E. and Chowdhry, B. S. (2009).

"Achievements, outcomes and proposal for global accreditation of engineering education in developing countries." Proceedings of World Conference on Educational Sciences 2009. pp 2557-2561

Njoku, P. C. (2002) "The Changing Roles of the National Universities Commission (NUC)". A paper presented at the 4th National Training Programme for Senior 12 University Managers (NATPSUMA) organized by the National Universities

Commission, Abuja, 10th December 2002.

Onwuka, E.N. (2009). "Reshaping engineering education curriculum to accommodate the current needs of Nigeria". Educational Research and Review, 4 (7), pp. 334-339. Retrieved From: http://www.academicjournals.org/.

Pugh S. (1993). Total Design: Integrated Methods for Successful Product Engineering, Addison-Willey Publishing Company, Inc. 